\title{
Wisdom in Mournful Tunes: Exploring the Major Themes of Igbo Oral Funeral Songs
}

\author{
Onyebuchi Nwosu ${ }^{1 *}$ \\ 1 Department of Languages/Linguistics and Literary Studies, Alex Ekwneme Federal University, Ndufu-Alike Ikwo \\ Ebonyi State, NIGERIA
}

*Corresponding Author: buchinwosu@yahoo.com

Citation: Nwosu, O. (2019). Wisdom in Mournful Tunes: Exploring the Major Themes of Igbo Oral Funeral Songs, Journal of Cultural Analysis and Social Change, 4(1), 05. https://doi.org/10.20897/jcasc/5848

Published: July 19, 2019

\begin{abstract}
Death often engenders emotional outbursts in the form of chants, songs and recitations. In most parts of Africa, the death of an adult member of the society goes with the rendition of some peculiar songs in honour of the deceased and to contemplate on death as a natural phenomenon. Among the Igbo of South-eastern Nigeria, it is anathema to intone a funeral song at a moment or location where there is no bereavement. Such acts attract severe verbal sanctions because oral funeral songs are special performances rendered during burial and funeral ceremonies. This implies that they are not merely ordinary songs rendered for nonjustifiable reasons but ones which have recognizable motives behind their rendition. The focus of this paper is to identify some strands of meaning which most Igbo oral funeral songs convey. It highlights their basic thematic constructs or the 'artistic representations' espoused in most of them. Applying Contextual Analysis as the conceptual theoretical framework, the paper analyzes the content of selected Igbo oral funeral songs and concludes that they have clear identifiable preoccupations because they express multifaceted shades of grief and serve valuable purposes in the various communities where they are rendered.
\end{abstract}

Keywords: thematic imports, oral funeral songs, Igbo, contextual analysis

\section{INTRODUCTION}

In a recent essay, one of the leading scholars of African oral literature, Ruth Finnegan acknowledges that the diversities and dimensions of African traditional verbal arts are continuously improving and expanding. As she puts it, "the study of African oral literature has in many ways been transformed" while the literature itself now includes "narratives, songs, epics, multi-media productions, broadcasts, political propaganda, oral-written intersections...the field is expanding to encompass changing and emerging genres as well as the once dubbed 'traditional"' (Finnegan, 2010, p. 25). In the lines above, she highlights the forms of African oral literature which have engaged the attention of scholars since she pioneered an elaborate and extensive study in the field; a venture which yielded the famous book Oral Literature in Africa, published in $1970 .{ }^{1}$ But having said that, she also points out that in spite of the bountiful leaps which the study of African oral literature has made, "there is still so much to do- to study, to collect, to store, to win appreciation for, to remain responsive to the changing and diverse wonder of African oral literary forms" (Finnegan 2010, p.25). She therefore calls for more vigorous analytical forays into African oral literature. This paper is conceived in response to this call; to re-evaluate the underlining thematic thrusts of Igbo elegiac performances with specific attention to oral funeral songs. 


\section{IGBO CONCEPT OF DEATH}

Death is marked by the cessation of breath which stops the functioning of the heart thus bringing the activities of all body organs and systems to an end. The death of any human being ignites pain in the heart of those whom the deceased has left behind. Death also elicits sorrow and sympathy for those who are closely affiliated to the deceased. Death generally is "an inescapable fact of life...the logical end of birth which in itself is the beginning of life as we know it in this world" (Opata 1988, p. 172). Death as explained above is a phenomenon that is inevitable for anything that has life or that which comes to life through birth. It is important to note that the interest of this study is on funeral songs rendered during incidences of deaths; that is, the death of a man or a woman, a son or a daughter, wife or husband, cousin or aunt, brother or sister, nephew or niece in Igboland.

The Igbo occupy an area in South-Eastern Nigeria. They are one of the most widely dispersed ethnic groups in Africa and "perhaps the ethnic group found abroad more in large numbers than any group in all Africa. There is perhaps no sphere where their influence is not felt, and no region where their fame has not been spread. There are no borders they have not crossed and no nations, however distant they [sic] are not found." (Onanuga et al 2012, p. 23) However, in Igboland and in other parts of Africa, there are three forms of death: "the first one is natural death, which comes as a result of ageing. Death can be caused by an individual through self-abuse like overindulgence in drinking, eating or the contraction of a disease. Malevolent spirits could also cause a person's death. These spirits could either be sent to the person in forms of witches/wizards, magic and charm or could visit the person in revenge for a wrong done them by the person" (Nwosu 2009, p. 143). A person's life can expire and wither just as a tree or plant does when its body can no longer sustain or regenerate itself; that is the result of ageing. Apart from this, one can suddenly die without any physically explainable cause even when the body organs and tissues are in good health condition. Such deaths, though natural, are in Igboland partly attributable to the ogbanje spirit. The ogbanje "are part human and part spirit beings whose lives are confounded by the added loyalty which they owe to spirit deities. A 'normal' individual is born owing his loyalty to his 'chi'. But an 'ogbanje's' life is complicated by being mixed up with the demands of paranormal deities. The most notable of these demands is that the 'ogbanje' will not be allowed to enjoy a full life cycle" (Achebe 1986, p 27). ${ }^{2}$ Ogbanje can cause such mysterious and incomprehensible death but that apart, one can do great harm to oneself and one's body by living a reckless life and the ultimate result is the destruction of body organs and ultimate death while some bad spirits or even humans who are known as akara ogiri - malevolent human and spiritual enemies in Igboland, can cause someone's death by inflicting a terrible terminal illness or disease on the person.

As an integral part of African society, funeral ceremonies in Igbo communities are hardly observed without singing, chanting and recitations. This is because "among the Igbo, the death of any member of a community, particularly the prominent or accomplished members of the community attracts the rendition of music and in some cases singing in honour of the deceased" (Onyeji 2004, p. 92). This expression of grief through singing and musical performances is uniquely peculiar to each community because it is spontaneous because "there is no common pool of funeral songs in Igbo as there is in the Christian religion ... Each area has its stock of funeral songs, which are sung according to the status, family links, and achievement of the deceased" (Chukwuma 1994, p.32). Such songs elicit emotional feelings that range from "anger to sorrow; anger at deprivation through death, and the hopelessness of amelioration." 3

\section{IGBO ORAL FUNERAL SONGS}

Singing is synonymous with humanity as "man is ontologically an expressive being ..." (Avorgbedor 1990, p. 208). A song is a vocal melodious tune that is individually or communally rendered. Most times it is accompanied by instruments which add much impetus to its musicality. Humans carry out many expressive acts but it is "in the song, however, [that] we reach the highest level of vocal manipulation....it is in the areas of instrumental accompaniment and audience participation that the song demonstrates its superiority to the other modes of performance." (Okpewho 1992, p.132). Distinguishing a song from other modes of poetic performance like chant and recitation, Okpewho maintains that "chanting, or recitation, is a technique of oral performance that stands halfway between normal speech and song ... [but] the performance of a song is also usually accompanied by music and dance in accordance with steps that are either culturally familiar or else related to the particular style dictated by the song" (Okpewho 1992, p. 133). He further maintains that "apart from having superior musical patterns a song can be performed by an individual or by a group but most times, people prefer group singing where they can participate in the singing, clapping and dancing as opposed to listening to solo performance by an individual artist."

Significantly, there is hardly any occasion in African traditional society that goes without singing and dancing. Africans, the Igbo inclusive, sing a lot because "for members of several traditional African communities, virtually every occasion necessitates singing ... Because songs permeate every aspect of African life and culture, they commonly derive their names from the different occasions on which they are performed or from which they are 
derived" (Okoh 2002, p. 156). The Igbo sing on every occasion and one of such occasions is the funeral ceremony which is associated with death, a phenomenon recognised as one of the major rites of passage. "Birth, marriage, and death constitute the rites of passage and as important landmarks in the life of an individual, they provoke great poetry" (Uzochukwu 2012, p. 273). Igbo funeral songs include sober and reflective singing and dancing carried out by members of an Igbo community during the funeral or memorial occasions slated to mourn a departed member, relation or friend of the community. The underlining factor is that singing and dancing are done in groups in such situations. This is one of the remarkable features of Igbo funeral song. It is performed by groups or in groups. The singing and dancing carried out by groups during burial and funeral rites to alleviate the pangs of bereavement and meditate on the phenomena of life and death in Igbo land are oral performances. The mournful situation that necessitates the rendition of Igbo funeral song gives meaning and credence to them and determines their actual mode of performance.

Performance is the live wire of oral literature. It is the main action that gives life to the dormant memorized oral text. However, "the term 'performance' has become extremely popular in recent years in a wide range of activities in the arts, in literature, and in the social sciences" (Carlson 1996, p. 4). According to Schechner (2002, p. 28), 'in the arts, 'to perform' is to put on a show, a play, a dance, an account." These are all observable physical acts, and commenting on the meaning of performance, he quotes Goffman (1959, pp-15-16) to have defined it as "all the activity of any given participant on a given occasion which serves to influence in any way any of the other participants ...". By this, the Igbo oral funeral songs to be discussed in this paper are collected as forms of various physical and verbal actions exhibited by people at funeral occasions. It involves "the live presence of the performers and those witnessing it ... [and there is] some intentionality on the part of the performer or witness or both..." (McAuley 2009, p. 45). In Igboland, men, women and youth make up the sympathizers—kinsmen and women, relatives, in-laws, colleagues, age-mates, friends and well wishers who perform oral funeral songs. They constitute the 'live audience' who chant, sing and dance in honour of the dead.

There are procedures to announce death especially in most Igbo rural communities where many people die in their homes because hospitals are not easily reachable. Whether the deceased is a man, woman, youth or a child, members of the immediate family are instantly informed and the elders among them will go and check the deceased's pulse. When it is evident that the person has died, women and children in the house are urged to raise cries and wailings. If the deceased is a child or an adult who is not yet married, arrangements are made for the corpse to be buried within a few hours of the death. But if the deceased is an adult or a man or woman married into the community elaborate funeral arrangements are made. The deceased will lie in state overnight during which a wake is observed. Within this time, various groups made up of men, women and youth take turns to chant, sing and dance. Most times, they sing and dance round the corpse as it lies in state. Funeral performances also continue the next day after the corpse has been interred.

A brief survey of the scholarship of Igbo oral funeral poetry reveals that the first work in the field is Poetic Heritage: Igbo Traditional Verse (1971) an anthology compiled by Romanus N. Egudu and Donatus I. Nwoga. As a collection of Igbo oral poetry with contributions from various parts of Igboland, the last section of the collection is entitled "Lamentation Poems." Under this section are four Igbo oral elegiacs with the titles: "Saviour", "Sorrows", "My Sister Lolo" and "Death has Crushed my Heart." Each of these oral elegiacs is written on the left page in Igbo language and translated into English on the right page. The Igbo version is dialectical while the translated version tries its utmost to capture the exact meaning. The only problem with the presentation is that no explanation or analysis is carried out to aid reading or appreciating the poems.

The second effort is by F. Chidozie Ogbalu who in 1974 published another collection of Igbo oral poems with a section named "Egwu Maka Onwu (Death Songs)." The only sore tooth in the collection is the absence of translated versions of all the oral poems including the death songs. This limits its scope of reach and understanding especially among non-speakers of Igbo language. Also, in her study of Igbo oral literature Helen Chukwuma made some prefatory remarks about " $A b u-o z u$ " funeral songs which she says are sung notably during funeral ceremonies or memorials. She argues that each community in Igbo land has their own "stock of funeral songs which are sung according to the status, family links and achievements of the deceased" (Chukwuma 1994, p. 38). Iroha Ebe Udeh also carried out a doctoral study entitled "Arts and Culture in the Elegiac Lore of Abiriba Igbo." As higher degree research that has oral funeral poetry as its focus, Udeh's study after investigating the themes that are explored in Abiriba Igbo oral elegy arrived at three. These are the "themes of sorrow and loneliness, philosophical reflections and social ethics" (Udeh 2000, p. 149). ${ }^{4}$

However Sam Uzochukwu pioneered the critical study of Igbo oral funeral poetry in his doctoral thesis submitted to the University of Lagos in 1981. In the work he classifies Igbo funeral poetry into two main types in terms of content: dirge and lament and explained each of them by vividly outlining their characteristics. ${ }^{5} \mathrm{He}$ further developed the core ideas he derived from that study into a book entitled Traditional Funeral Poetry of the Igbo (published in 2001). Though the discussions in the book are extensive, there are some themes that manifest in Igbo traditional funeral poetry which are not discussed. Apart from the book, Uzochukwu has written an article 
"Traditional Poetry as a Mirror of Cultural Values: The Case of Igbo Funeral Chants" where he infers the Igbo belief system, culture, norms and values from some chants which are performed during funerals. However, as a scholar with enormous passion for the expansion of the scope and intensity of Igbo oral funeral forms, he recognises the lapses in his method and calls on Igbo scholars to undertake separate studies of each of these delivery modes of Igbo oral funeral poetry: "Clearly, there is ample room for further investigations into Igbo traditional funeral poetry through specific research projects on each of the three modes: the chant, the song, and the recitation (Uzochukwu 2001, p. 116).

\section{Theoretical Framework}

Discussions in this paper focus on some Igbo oral funeral songs that I collected from fieldwork and observations I carried out for my doctoral dissertation which I defended at the University of Abuja, Nigeria in 2017. In the course of the research, I recorded numerous oral funeral songs from Umuawuchi-a rural Igbo community. These songs were transcribed and also translated into English. They constitute the main texts which this article examines to unravel their thematic thrusts. The conceptual literary framework employed in the analysis of the Igbo oral funeral songs is contextual analysis. On the meaning of this method, "contextual theories of meaning assert that concepts precede precepts;... the range of contexts within which utterances occur extends from the narrowly linguistic (phonetic or morphological) to the broadly philosophical, and the task of literary criticism can be seen, in part, as the need to relate words, phrases, sentences and other parts of literary works to their linguistic contexts" (Childs and Fowler 2006, p. 38). A contextual analysis then involves an appraisal of the manner in which words that make up a literary piece are arranged or the way they associate with each other as well as relating the meaning of the words to the surrounding socio-historical and psychological events that gave rise to the work.

For the Igbo oral funeral songs to be discussed in this paper, death offers the ambience that gives rise to their rendition; so, their meanings are better inferred from this framework. Looked at from another angle, contextual analysis is "simply an analysis of a text...that helps us to assess that text within the context of its historical and cultural setting, but also in terms of its textuality- or the qualities that characterize the text.... contextual analysis combines features of formal analysis .....and aesthetic conditions that were...in place at the time and place when the text was created" (Behrendt 2008, p. 1). As a method, it makes use of some conventional literary techniques that dwell on the thematic and stylistic imports of a literary text while complementing it with additional investigation into the events and activities that give vent to the piece. Acknowledging that these Igbo oral funeral songs are products of grief, this article evaluates their literary values in terms of the meanings they bear and the subject matter that is projected through them.

\section{THEMES IN IGBO ORAL FUNERAL SONGS}

The significant character of any literary piece of art is that it has a meaning which it communicates or a sense which is decipherable from it. This is popularly called the theme, the message or the subject matter. This is "any representation of reality by the use of words done through character, action, situation, setting and belief' (Udeh 2000 , p. 240). Such representations generate or elicit meanings which are passed across to both the audience and connoisseurs by literary producers through their actions in a given situation. They offer a "picture of reality in a literary composition, which may be based on character, action, situation or setting, time and place" (Mbah and Mbah 2007, p. 249). The theme of a literary work therefore includes the major issues, topics and ideas which it contains and transmits to people. As a kind of literature, "oral literary forms not only treat but also shed valuable insights into human nature and the universal themes of life, death, marriage, greed, jealousy, corruption and the problem of good and evil" (Akporobaro 2004, p. 16). Death is one of the themes enumerated above and this is best captured in the traditional elegies which most times are in form of chants, recitations and songs. Of utmost interest to us in this paper are oral funeral songs, for in Africa, "at the death of the individual, some songs lament the loss of the physical life while other songs give consolation for a life well lived and usher the deceased into a glorious company of the ancestors" (Okpewho 1992, p. 132). Commenting in a similar vein, Emezue (2001, p. 24) argues that a few themes dominate African dirge and highlighting them she posits that "the preoccupation of most dirges is that of loss and separation while the mood is filled with sorrow and sadness. At times [such] feelings progress into deep-seated frustration and helplessness."

Most Igbo oral funeral songs are short and in most instances pursue a single theme. This is a characteristic that they share with Efik song text which "deals with a single theme and treats it as briefly as possible" (Erim 1990, p. 56). The reason for this is not far-fetched because as mourning and sorrow-laden songs, Igbo oral funeral songs deserve to be short and have meanings that are uncluttered so as to make for easy understanding, memorization and singing. Their terse and concise features facilitate easy comprehension and their composers take into account the unsteady mood of the bereaved for whom the songs are most times rendered to console. The songs are precise 
because the performers are careful not to belabour the audience with obscure expressions or subject matter. Below are the basic themes explored in most Igbo oral funeral songs:

\section{Anger, Sorrow and Sadness}

Whenever death occurs in Igbo communities, it causes anger, sorrow and sadness. These feelings are vividly expressed in most Igbo oral funeral songs. The songs are not only deployed by the performers to mourn the dead but their rendition helps to express pent-up emotional feelings and release grief. In the song below, some youths express their anger and sorrow over the death of a young man. Within the few lines, the young people show their grief over the untimely departure of a promising young man:



The persistent repetition of "anger" helps to register their disapproval of the death as well as their sorrow. But at the end of the song, they reveal the reason for their anger. In another instance, the performers take the role of complainants who are reporting that they are unhappy because of a valuable possession that death has snatched away from them. So while sounding consolatory they are expressing their profound unhappiness:

Umu ibe ndo, umu ibe ndo

Umu ibe ndo, umu ibe ndo

Nkwn chara acha egbe biara buru

Ebe o buru ya

Obi adighi anyi mma. (A2)

My people sorry, my people take heart

My people sorry, my people take heart

This ripe palm-fruit

That's whisked away by a kite

As it carried it, we are not happy. (B2)

It is said that whatever could not be overcome should be borne with equanimity. So, aware that it would amount to a futile attempt to run after the "kite" which has "whisked away a ripe palm-fruit," the performers (mourners) express their grief over the loss by stating that they are not happy but that they should take heart. From the way the song is structured, the heavier part of the theme tilts towards an expression of sadness over the nefarious activities of death.

\section{Loss and Frustration}

Apart from expressing anger, sorrow and sadness, most Igbo oral funeral songs explore the themes of loss, loneliness and frustration occasioned by the death of a beloved relation or friend. In the song below performed mostly by women, the major thrust is the unforgettable nature of the death of one's parent. Such death is seen not only as a heavy loss but an occurrence that is indeed definitely hard to forget and overcome:

$\begin{array}{ll}\text { S: } & \text { Onye nna ya nwuru? } \\ \text { Ch: } & \text { O na agba nchebu } \\ \text { S: } & \text { Onye nne ya nwuru } \\ \text { Ch: } & \text { O na agba nchebu? } \\ \text { All: } & \text { O na agba nchebuo ooo } \\ & \text { O na agba nchebu! } \\ & \text { Metumaraibe! } \\ & \text { O na agba nchebu! }\end{array}$


Chiawolamoke!

O na agba nchebu! (A3)

S: $\quad$ One whose father dies

Ch: Does he forget it?

S: One who loses his mother

Ch: Does he forget it?

All: Does he forget it?

Is it easily forgotten?

S: (calls) Metumaraibe!

Ch: Is it easily forgotten?

S: Chiawolamoke!

Ch: Is it easily forgotten? (B3)

In Igbo language, the use of rhetorical questions like the one we have in the song above is also an affirmative statement which is as good as stating the obvious. Though most lines in the song are interrogative, the performers are merely stating the fact that such death hardly goes out of one's mind. This can be compared with the dirge below which portrays the mournful cries of a widow whose husband's death has rendered her lonely and vulnerable:

Dim lee I hara m gawa
Mu na ony ga ebi?
Ewooo! I hara m gawa
Mu na onye ga ebi? (A4)

Oh my husband you left me and departed

Whom will I live with?

Ewooo! You left me and departed

Whom will I live with? (B4)

The death of the woman's husband in the above song has made her dread the loneliness she is going to face and as such she weaves her frustration into a song.

\section{Empathy and Consolation}

However, in spite of the feelings of anger, sorrow and frustration which the occurrence of death spurs, Igbo oral performers use songs to also perform the important role of empathizing with the bereaved family by exhorting them to take heart since death is an unavoidable misfortune. In the song below performed at the funeral of an old woman who died at a ripe old age, her death is regarded not as a heart-breaking occurrence but that which occurred at its own time - at a very ripe old age. The bereaved through the song are consoled to take heart and 'clean their eyes':



The tone of the song is completely generic as no particular person is mentioned but rather it could be addressed to anyone who is mourning the loss of a departed one. The reason for the humble request "clean your tears" which also implies "cease crying" or "reduce your grief" is that the death is perceived to have occurred at the appointed time and as such it is irreversible. It also shows the people's attitude towards death; death is not taken with so much grief since it is an unavoidable occurrence.

Similarly, another Igbo oral funeral song encourages those befallen by certain misfortunes like death to take heart and bear it with great fortitude. This is the theme of a song performed by both women and youth during the 
funeral of a young lady in an Igbo community. With the song, the performers empathize with the parents and encourage them to endure the irreparable loss:

Dibe dibe dibe

Ndidi ka mma

Onye ibe mere ya diwe ya

Ndidi ka mma! (A6)

Endure, endure, endure

Endurance is the best

One whom misfortune befalls

Should endure it!

Endurance is the best! (B6)

This is almost in line with the mantra "endurance is the best policy" and going by the manner in which it is used in the poem, endurance incorporates perseverance, fortitude, patience and forbearance; and the poet-speaker in the song solicits that whoever encounters any misfortune (death being the most painful) should brace up and endure it. Another song specifically pleads that anyone experiencing the vicissitudes of life such as death should refrain from crying for such an approach does not solve any problem. This is the theme of the song below which is performed by women at the funeral of an old woman:
S: Onye ihe mere kwnwa onu o
Uwa e bighi n'akwa
Ch: Onye ibe mere kwuwa onu ya
Uwa e bighi n'akwa! (A7)
S: $\quad$ One befallen by misfortune should keep quiet
For crying does not solve earthly problems
Ch: One befallen by misfortune shouldn't cry
For crying would not end the world's problem! (B7)

\section{Theme of Camaraderie}

The term camaraderie refers to a spirit of good friendship and loyalty among members of a group. It is this spirit of togetherness, a kind of brotherly or sisterly bond which unites people not related by blood links as if they are relatives. People in such a group bond together, bear burdens together and socialize, mingle and interact with one another. Where there is such spirit, a misfortune that befalls any member is seen to have befallen the whole group while solidarity is shared with a member up to the point of death. During the funeral ceremony of an old woman in Umuawuchi, the study community, a group of women under the aegis of Ezinne (Good Mothers' Group) performed a funeral song which vividly illustrates this theme:

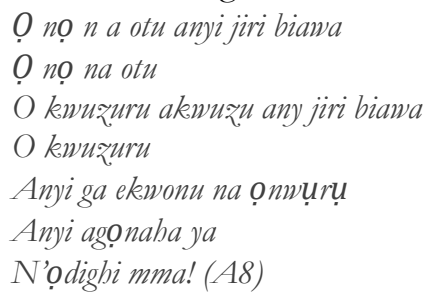

She belongs to our group, that's why we are here

She belongs to a group!

She is a staunch member, that's why we are here

She is a staunch member!

We won't deny her

Because she is dead

For that won't be good! (B8)

Together and in one accord, the women express their unalloyed solidarity with their deceased member and with that they profess a kind of communal bond which ties them together. The woman's death has afforded them the opportunity to reveal their motive and mission; and because she is a staunch member of the 'Good Mothers' group, that is why they are gathered to pay their respects. This is an indirect way of encouraging people who belong to any group or association to take their membership of such groups seriously. They also encourage organisations, in turn, to honour their members who answer the irresistible call of death. In most Igbo communities, the presence of a large number of relatives, sympathizers and mourners at any funeral serves as a balm to the grief of the bereaved. Such convivial presence ameliorates grief, brightens the mood and helps to allay the pains and sorrows ignited by death. 


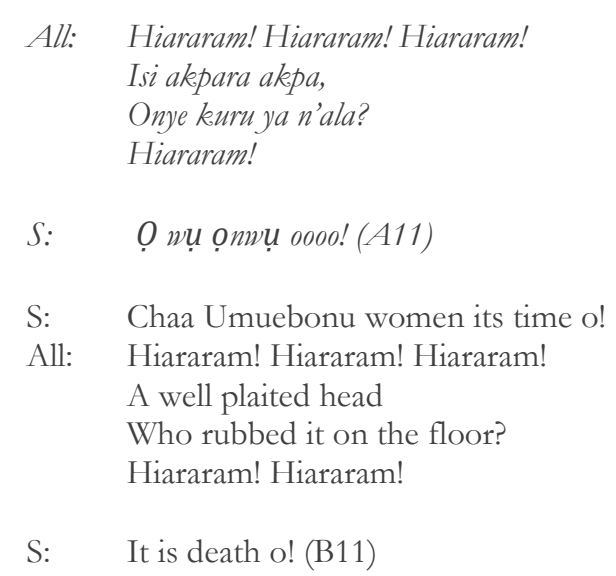

In the song, the women set off with a repeated rendition of an idiophone and chant "Hiarararm!" to set a musical pitch for their funeral performance. Then appropriating the metaphorical image of "isi akpara akpa (a plaited head), they asked a question: "who rubbed it on the ground?" Quickly providing the answer, the song leader says that it is death. Thus, death is revealed as a destroyer of valuable things. In using the image of plaited-head, the women put into account the fact that women cherish fine plaited hair. Not only that, it takes so much time, labour and resources to plait the hair. For death to rub this treasured human creation on the ground means that it is not only heedless of valuable things but can wreak great havoc by destroying them too.

\section{Theme of Death's Inimitability}

The theme of death's inimitability is also prominent. Covered under this umbrella is the ubiquitous and omnipresent nature of death as exemplified in the Igbo funeral song below:

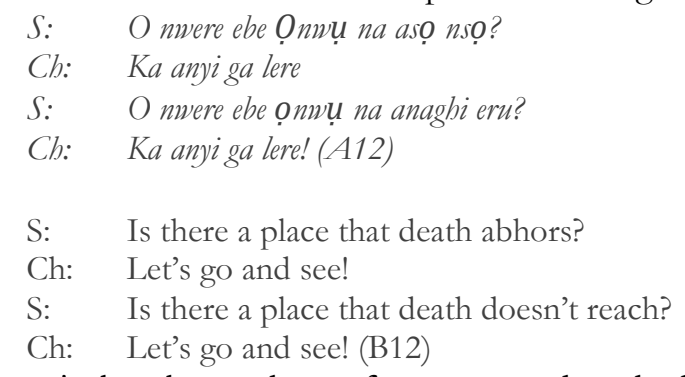

In rhetorical parlance, the performers wonder whether there is a place that death's life-destroying reach cannot extend to. From the way the song is structured, they are merely stating the markedly obvious- that death has no barrier and it abhors no land but reaches to all ends of the earth where it carries out its dastardly activity of reaping lives. Compare the above song with this one which portrays death as an impregnable and indestructible phenomenon that builds its house atop a boulder and does not discriminate or show any preference in its mode of attack:

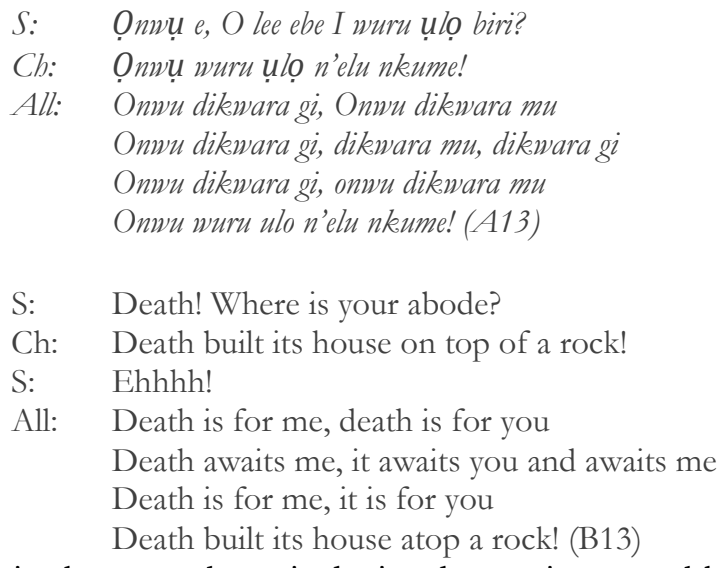

Death in the song above is depicted as an impregnable entity that builds its house atop a rock where nobody and no one can reach to talk to it or destroy it, so it goes about proudly preying on humans and has no preference for the kind of people it destroys.

\section{Mysteriousness, Inevitability and Heartlessness of Death}

Some Igbo funeral songs portray the mysteriousness of death. In such songs death is presented as an entity that is not only mystical but is also invincible. This is the underlying current of Song Number 14 below: 
Uwa m lee uwa lee, uwa wn obughara

Onye ma onye o ga awunu echi

O lakpuru ga bewe

Hee heee! E hee hee heee!

Onye ma onye $O$ ga awunu echi

O lakpuru ga bewe! (A14)

My world, this world is a twisting and turning world;

Who knows whose turn it will be tomorrow

Will remain indoors and keep crying.

Hee heee! E hee hee heee!

Who know whose turn it will be tomorrow

Will remain indoors and keep crying. (B14)

In the song, the world is presented as an unsteady ever-turning and twisting setting while death's movements are hidden from sight. Because it is difficult to completely grasp the nature of death or even pinpoint the time or the next person it will take away, the song explains that humankind is relieved of the gloomy atmosphere which might otherwise pervade the earth. As the song puts it, whoever knows whose turn it would be to die the next day will be condemned to perpetual brooding and contemplation. But the good thing is that Nature in its infinite wisdom denies mortals access to such knowledge. So human beings are allowed the freewill to play around and only succumb to death whenever it chooses to suddenly strike. Another Igbo oral funeral song, Song Number 15, also plays on the fact that death is inevitable and its call is not only irresistible but impossible to delay:
Gwuzoro m adighi ya
Chere $m$ adighi ya
Gwuzoro m adighi n'ọwu ee!
Nri ahu m shiwere
Ka $m$ rie ya ma gawa
Chere m adighi n'ọwu ee! (A15)
Wait for me isn't in it.
Tarry a while for me isn't there too
There is no excuse when death calls!
That food I put on fire
Let me eat it before going
Death doesn't take any excuse! (B15)

Performed by women during the burial ceremony of an old woman in the study community, the song uses the scenario of death not even harkening to the plea of the hungry, to remark that it takes no excuses nor is deceived by any gimmick or trick. Death in this regard is depicted as a heartless and ruthless entity.

\section{Death's Friendlessness and Stoicism}

Igbo oral funeral performers in Song Number 16 highlight death as an entity that is friendless:
S: $\quad$ Onye wu enyi onwu?
Ch: Onwu enweghi eny!
S: $\quad$ Onye wu enyi onwu?
Ch: Onwụ enweghi enyi
S: $\quad$ Papa anyi 0 wu enyi onwu?
Ch: Onwu enweghi enyi!
S: $\quad$ Papa anyi 0 wu enyi onwu?
Ch: Onwu enweghi enyi
S: $\quad$ Onye wu enyi onwu?
All: Onwu enweghi enyi ma nchaa!
Nchaaa nchaa nchaa! (A16)
S: Who is death's friend?
Ch: Death has no friend!
S: Who is death's friend?
Ch: Death has no friend!
S: Is our Papa death's friend?
Ch: Death has no friend!
S: Is our Papa death's friend?
Ch: Death has no friend
S: Who is death's friend? 


\section{All: $\quad$ Death has no friend at all!}

At all! At all! (B16)

The song explains that no one is death's friend and to underscore this point, the last two lines emphasize that death has no friend "at all!" Compare the above with Song Number 17 which dwells on the stoicism, boldness and affable spirit developed in response to death's repeated and persistent incursions. Because of its regular "attacks and exploits" which ultimately decimate their population, Igbo people are beginning to develop an adamant and carefree attitude towards death. They are no more afraid of death because they are sure that it will definitely come when it will but their fear now is more on the kind of illness or disease that will result in their death. This is expressed in Song 17 below:

Egwu na atunu $m$
O wu egwu kee e?
Egwu na atunu $m$
Ihe na atu m egwu
Bu ihe m ga aria anwu
Egwu na atunu m
O wu egwu kee e? (A17)
Which fear do I entertain?
Which fear do I have?
The only fear I have
Is the kind of illness/disease
That will lead to my death
Which fear do I have? (B17)

The first two lines of the song which are also repeated in the latter part carry an inverted question which in the typical Igbo understanding is also an affirmation which means "I have no fear or I am not afraid." In the song, there is the heightened note of talking-down to or belittling death. Yet, more concern is shown towards that which will make one vulnerable to death.

\section{Philosophical Themes}

One significant feature of Igbo oral funeral songs is that they carry some values, norms and philosophies of the people. As lachrymal expressions, they bear the pulse, thoughts and concerns of Igbo people. These include their communal principles, beliefs and attitude to life and death. In most parts of Igbo land, two events are exceedingly remarkable in a person's life; these are a person's time of birth and death. The community holds these events in high esteem and that is why elaborate ceremonies go along with them. These events constitute the central thought of Song Number 18:
S: Abali abuo!
Ch: $\quad$ Abali abụo ka mmadu nwere n'uwa
Ubochi ọmumu, n’ubochi onwụ ya! (A18)
S: $\quad$ Two days!
Ch: Only two remarkable days does one have in this world
The day of birth and that of his death! (B18)

Because of the importance that the Igbo attached to these two events, the funeral song hyperbolically sums up all the days a human being has in his or her lifetime on earth to be equal to just only two days- "the day of birth and that of his death." These days are strikingly noteworthy in the life of any individual in the community and as such they stand out among what the Igbo call 'the rites of passage' which are remarkable events in a person's life.

Another belief of the Igbo that is clearly buttressed in their funeral song is their penchant for sagacious reasoning and the desire that the young should outlive the elderly:

o kacha mma nwa lie nne ya

o kacha mma nwa lie nne ya

Nwa mara ihe ya lie nne ya

o kacha mma nwa lie nne ya

Mge nne ya kara nka! (A19)

It's good for a child to bury the mother

It's good for a child to bury the mother

A sensible child to bury the mother!

It's good for a child to bury the mother

When the mother has grown old! (B19)

The same thought in the song applies to a father. A lineage is said to be on the path of perpetuity when the children in such a family are wise and not foolish, for as the Igbo people would say "amaghi-ihe wu ibe na eshi ama $\mathrm{O}$ 
bughi iberibe -foolishness and not waywardness is the character that can lead a lineage into extinction." In Igbo parlance, 'foolishness' is called 'amaghi ibe'- lack of knowledge, while 'waywardness'-- 'iberibe' is a kind of misdemeanour. The foolish son would waste his parents' resources and even his own life or even disappear and never to return home but the wayward son may along the line impregnate a woman, marry and bear children whom he would in the end (after so many years) bring home, and so perpetuate his lineage. The caveat embedded in the song "a sensible child" is a tacit call for children to be wise and a reminder that not all children are capable of befittingly burying their parents, but only the wise ones can. Also, "burying one's mother" carries the sense of growing up sensibly and becoming someone who can take care of the mother, make her happy by giving her grandchildren and give her a befitting burial when she dies. However, when the children are not wise, the parents will live to bury them and this casts doubt on the ability of the lineage to be regenerated.

\section{Exhortations on Life and Death}

Among the Igbo, some elegiac songs make certain pronouncements about death while others advise the living. Song Number 20 below, for instance, is a heart-rending request, a passionate appeal that death should have taken money instead of the life of a colleague which it wickedly snuffed out:

Onwu I mara were ego

Hapuru anyi nwanne anyi o!

Onwu I maara buru ego

Hapuru anyi onye otu anyi o! (A20)

Death, you should have taken money

And leave our brother for us!

Death you would have carried money

And leave our colleague for us! (B20)

But as if death is deaf and heartless too, it does not lend an ear to such heartfelt prayer, for daily it swoops on many Igbo people leaving trails of pain, sorrow and loss. In some instances, the performers are sarcastic and intone highly satiric but jocular songs. They caricature the day they will die saying that on that fateful day, while some people will be crying and grieving, others will be laughing and rejoicing:

S: $\quad$ Mu a rarawa ndu a maghi m ezi o wu

Ch: Mu a rarawa ndu a maghi $m$ ezi o wu

S: $\quad$ Mu a rarawa ndu a maghi m ezi o wu

Ch: $\quad$ Mu a rarawa ndu a maghi $m$ ezi o wu

S: Ezi O ga wu!

Ch: Ndi n'ọchi, ndi n'akwa!

S: Ezi Oga wu!

Ch: Ndi n'ọchi, ndi n'akwa! (A21)

S: $\quad$ Let me enjoy life for I don't know when it will be;

Ch: Let me enjoy life for I don't know when it will be.

S: $\quad$ Let me enjoy life for I don't know when it will be;

Ch: Let me enjoy life for I don't know when it will be.

S: For on that fateful day!

Ch: Some will be laughing; some crying!

S: $\quad$ For on that fateful day

Ch: Some will be laughing; some crying! (B21)

Through the funeral song, the performers make a subtle comment that no one is totally loved or hated in the world and more so, death is an inescapable price which every living being must pay. So, it is better for one to live life to the fullest by being happy and joyful. They wittingly exhort people to seize every moment and enjoy it because death always lurks at the corner. Such an oral funeral song counsels the living just like the next one which advises them not to be miserly or have an inconsiderate lifestyle:
S: $\quad$ o kpa aku eri eri
Ch: I I hula otu onụ di ndi nwüru anwụ
S: $\quad$ Onye na akpa aku, ata aku
S: $\quad$ Lee nu otu onụ di onye nwurụ anwụ
$S: \quad$ Omegbu nwa ogbenye
Ch: Biko kpachara nu anya gi
S: $\quad$ Omegbu nwanyi isi mkpe
Ch: I kpo nke gi ala mmụo? (A22)
S: $\quad$ He who gathers wealth without enjoying it
Ch: Have you seen how the mouth of the dead looks? 


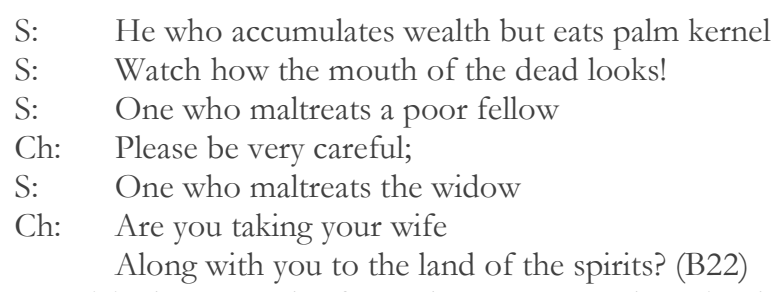

Taking a satirical stance, the funeral song warns the miserly to desist from "ikpa aku, na ata aku—'accumulating wealth but chewing only palm kernel." That is the apogee of self-hatred and neglect! The song warns anyone who is accumulating wealth to also enjoy the wealth and not be miserly. Moving away from misers, the song engages those who harass and subjugate the poor and the widows, exhorting them to be careful of their acts, for they will surely die one day and those they leave behind will equally be maltreated. The warning to the miserly (that they should look at the mouth of the dead) can best be understood in the days gone by, when the mouth of a corpse would usually firmly be tied with a white cloth, meaning that nothing can go inside it again. So, the people are enjoined to enjoy their wealth while alive. Many other moral lessons are put forward for the living in many other Igbo oral funeral songs, for as the Igbo would say onye na akwa onye nwuru anwu, na akwa onwe ya-one who mourns the dead is as well mourning oneself.

\title{
Igbo Oral Funeral Songs: Modern and Christian Influence
}

In a monograph entitled An Outline of Igbo History, a notable Igbo scholar, Adiele Afigbo (1975, p. 19) observes that the influx of Christian ideology in Igboland has somehow ruffled the traditional systems of belief and practice. "In sum therefore, this new society emerging as a result of the conflict between Igbo thesis and the colonial antithesis is one in which elements of both still jostle for supremacy." However, quoting Sylvia Leith-Ross, he paints a picture of the kind of scenario created by this trend which has produced an Igbo society that is a melange of the traditional and Christian order:

\begin{abstract}
...with no strain nor conflict 'the modern Igbo' can attend communion and believe in 'medicine', keep, until he is found out, a 'church' wife and several native marriage wives, tie up preciously in the same corner of a handkerchief his rosary and the shaped bit of 'iron for juju' made for him by an Awka blacksmith, plant side by side in the garden round his new cement and pan-roofed house the hibiscus of 'civilization' and the ogirisi tree of pagan family rites. (Afigbo 1975, p. 19)
\end{abstract}

The excerpt above points to the Igbo proclivity to merge Western ideals with the traditional thus creating a kind of religious syncretism. Such predisposition to equally commit oneself to both traditional and Christian religions which were observed in the early years of colonial rule has remained till the present moment. In various parts of Igboland, members of some new Christian Pentecostal churches (Believers' Gospel Mission, Assemblies of God, Deeper Life, The Lord's Chosen, The Redeemed, Living Faith etc.) adhere strictly to Biblical injunctions and hardly participate in any form of traditional engagement. However, there is a large number of Orthodox Christians (Catholics, Anglicans, Abosso Apostolic Faith, Nation Builders, Presbyterian, Methodist etc.) who though they are Christians, actively participate in traditional activities like rendering oral funeral song during burial ceremonies. With such composition, funeral observances in most Igbo communities take two different dimensions. While the burial of a professed Pentecostal Christian takes a pure Christian outlook, that of an Orthodox Christian is a blend of Christian and traditional observances.

In the course of this study, efforts during the fieldwork were concentrated on the funeral ceremonies of some orthodox Christians where it was observed that there was a smooth interplay between Christian obsequies and traditional funeral proceedings. Such a phenomenon is neither new nor peculiar to Igbo land; it is also noticeable in some other African communities. For instance, Gbolo Sanka (2010:195) in his study of the dirge of Sisaala people of Ghana observes as follows:

The reality is that the two religions [Christianity and Moslems] as well as Western education have come to meet the culture of the people. And though the majority of local people have joined either of the two religions, they still find no problem in mourning the dead in the traditional way alongside Christian and Moslem practices. The new development is that it is the followers of the two religions who prepare, handle, and bury the corpse in the Christian or Moslem context. Dirge performance is however done the traditional way with the whole community participating in the rendering of such pieces.

The same scenario is noticeable in various Igbo communities where the practice of rendering Christian hymns/choruses and oral funeral songs during wakes and funeral ceremonies is observed. Some Christian hymns and choruses have even been translated into Igbo language while some are entirely formulated and composed in Igbo. However, due to constancy and consistency of rendition during funeral ceremonies in some Igbo 
communities, some Christian hymns have been memorised by the natives who now render them as part of their oral funeral lore. In moments of bereavement for instance, such Christian Hymns and choruses are rendered side by side the traditional funeral songs. Sometimes, Church choirs are also invited to participate in burial ceremonies that have traditional rites. To this Uzochukwu (2001: 117) remarks that the joint rendition of both Christian and traditional funeral songs in a burial in Igbo land is as a result of some awareness of the fact that the object of both Christian and traditional performances is to accord the deceased an honourable burial and facilitate his/her rest in the world beyond. "There is now a growing awareness in some areas of Igboland that the traditional mode of funeral celebration is not inherently a fetish nor is it necessarily at variance with the Christian mode, for both aim at giving the deceased a befitting funeral which will guarantee for him some form of life after death." Owing to this, some popular English Christian hymns which have been translated into Igbo have found a place in the Igbo oral funeral song 'bank.' Once the choir intones any such translated hymn versions during burial ceremonies, the majority of the people (whether Christians or non-Christians) who are present at the funeral ceremony will sing all the stanzas. Below is one of the stanzas of a popular Christian funeral hymn "Rock of Ages". Its Igbo translation has become widely accepted as an Igbo oral funeral song. In the song, man in death is portrayed to be at his weakest point pleading to God (The Rock of Ages) to shield him from the destructive vicissitudes of life.

\author{
Ebem n'ekume ndu nka \\ Mgbe m'mechiri'anyam n'ọwụ, \\ Mgbe m'gala n'uwa ozo \\ Hu Gi n'oche-ikpe Gi \\ Nkume nke ebighi-ebi \\ Kwe ka m'zoro n'ime Gi \\ (Ekpere na Abu p. 28)
}

\footnotetext{
While I draw this fleeting breath

When my eyes shall close in death

When I soar through worlds unknown

See Thee on Thy judgement throne

Rock of Ages cleft for me

Let me hide myself in Thee.

(www.hynal.net/en/hymn/h/1058)
}

Similar to this is a prayerful Igbo oral funeral song requesting that a deceased should go in peace; rest in perfect peace. But in doing this, there is the aura of mournful regret because the singers face the realisation that they will not see the deceased again in his/her physical form:

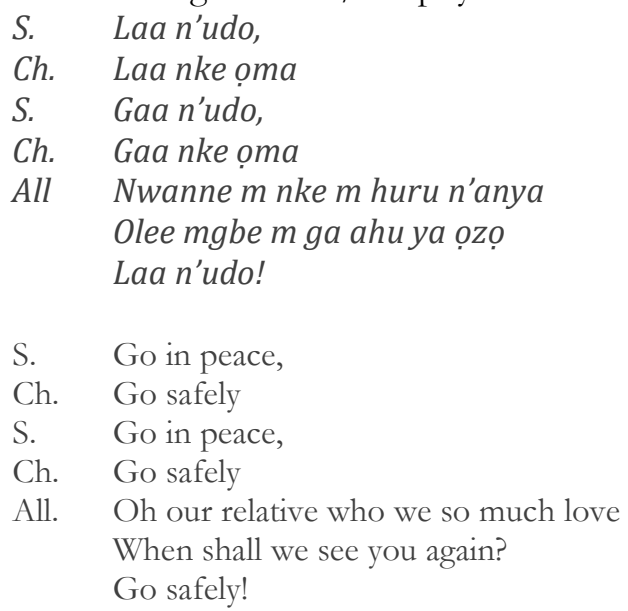

The song is hymn-like and has a sombre lyric. It is usually rendered without any instrumental accompaniment at the peak of the funeral ceremony when the corpse has been lowered and grave-diggers are shovelling sand into the grave to cover it. It brings mourners and sympathizers to the grim realisation that the deceased will not be physically seen again.

Furthermore, to buttress the level of interplay between Christian ideals and traditional tenets, some Igbo oral funeral songs are steeped in Christian teachings yet they are performed by native people, some of whom are not Christians. For instance, in the song below, there is an allusion to the creation story in the first book of the Bible, Genesis, where it is said that God moulded the first man with sand after which he breathed into him, the breath of life:

Aja ka anyi bu

Aja ka anyi ga algahachi 
Chukwu kere uwa

Onwu siri na mmehie bia

Sand we are

Sand we shall return back to;

Oh God creator of the world

Death came through sin

The last two lines of the song equally allude to the origin of death which is biblically traced to the sinful disobedience of Adam and Eve. In another song, the allusion is to Job's popular saying in the Bible that he came to the world empty handed and he will go back the same way:

Agbara m aka bia n'uwa
Agba m aka ala
Ihe n'ile m nwere n'uwa
Onweghi nke mi ala!
I came into the world empty-handed
I will leave empty-handed
All that I have in the world
There is none I will take along!

This song aims at dissuading people from placing so much emphasis on the acquisition of earthly riches and wealth. Incidentally, the song was encountered at the burial ceremony of a wealthy young man whose corpse was repatriated from Lagos to his community, Umuawuchi in Imo State, South-eastern Nigeria for interment in September 3, 2013. The event was extremely painful because he was yet to marry, though he was very rich and possessed one of the magnificent buildings in the community. He rarely identified with any Christian sect while alive, yet, a Pentecostal Christian pastor was hired to officiate in his funeral proceedings. The gathering during his funeral was made up of Christians and traditionalists, hence why this native song with some Christian leanings was rendered.

During the course of this study, it was discovered that in recent times, funeral ceremonies in most parts of Igboland hardly go without the hiring of modern musical electronic equipment called obe akwa wwa- 'that which cries for the world." They are operated by individuals who are popularly called 'DJs', and the inability of a family to hire such equipment is seen as a mark of poverty. The basic electronic musical instruments that make up a set of obe akwa una include: a deck or sound mixer, an amplifier, a cassette or compact disc player, or these days a laptop, high calibre speakers with a horn speaker, microphone and an electrical generating set. The operator or DJ is sometimes hired to play recorded music throughout the funeral period. In addition, some wealthy families go to the extent of hiring live (musical) bands to play and perform during funeral ceremonies. The key instruments for the live bands include among others, a set of guitars, a set of modern musical drums and cymbals, musical organ, microphones, tape-deck, amplifiers, speakers and an electrical generating set. The use of these forms of electronic musical entertainment during moments of bereavement is fast gaining ground as it also helps the bereaved and other sympathizers to mourn the dead.

The emergence of DJs and live bands pose serious threats to the rendition and perpetuation of oral funeral songs. In one funeral ceremony that I attended during the last days of 2015 , most sympathizers who would have performed some oral funeral songs during the occasion preferred to sing along and dance to the tunes of the DJ. With attention now shifting to the music played from electronic musical instruments or by live bands at the expense of communal rendition of oral funeral songs, the future and survival of live performances of oral funeral songs in most Igbo communities is uncertain. On the basis of my research findings, it appears that the interest of people in the performance of Igbo oral funeral songs is fast declining.

\section{CONCLUSION}

From all the discussions so far, it is evident that oral funeral songs are important instruments deployed by the Igbo to mourn the dead and educate the living. The paper also reveals that Igbo elegiac songs are not bereft of artistic preoccupations as they explore themes including anger, sorrow, sadness, loss, frustration, empathy, camaraderie and reincarnation. It is also observed that in some Igbo oral funeral songs, death is portrayed as an inimitable, friendless, inevitable and mysterious entity that is also a heartbreaker and a havoc-wreaker. Also, some of the elegiac songs are imbued with dynamic philosophical tropes through which the people attempt to unravel the mystery surrounding the meaning and characteristics of death as well as its incomprehensible modus operandi. In all, it is clear that the living gain knowledge, wisdom and understanding through the performance of oral funeral songs during the burial and funeral ceremonies that they carry out in honour of fallen members of the Igbo society. 


\section{NOTES}

1. Ruth Finnegan's book is a magnum opus of a kind as it has remained an important reference text on African oral literature. She has continued to champion other studies that explore and expand folklore studies in Africa.

2. Chinwe Achebe carried out a detailed and methodical investigation into the nature and world of the Igbo metaphysical phenomenon of Ogbanje and her book on it is revealing and insightful as she discusses its characteristics, diagnosis and some traditional intervention strategies that can be deployed to treat it.

3. These three main points are highlighted as the major themes of Igbo oral funeral poetry which covers chants, songs and recitations. However, the discussions on them are not detailed.

4. The PhD dissertation was successfully defended in the University of Nigeria Nsukka, Nigeria in 2000. In the study, Udeh discusses what he calls the four basic themes of Igbo elegiac lore.

5. He classified Igbo traditional funeral poetry into lament and dirge. To explain their different meanings, he draws on Finnegan's (1970, p. 147) citing of J. H. Kwabena Nketia. Here, dirge refers to the deceased while lament refers to death in general. See Uzochukwu (2001, pp.24-26) and J. H. Nketia's Funeral Dirges of the Akan People (1955, pp. 27-28).

\section{REFERENCES}

"Rock of Ages, cleft for me" hymnal.net. Available at: https://www.hymnal.net/en/h/10587

Achebe, C. (1986). The World of Ogbanje. Enugu: Fourth Dimension.

Afigbo, A. E. (1994). An Outline of Igbo History. Owerri: Rada.

Akporobaro, F. B. O. (2004). Introduction to African Oral Literature. Lagos: Princeton.

Avorgbedor, D. (1990). Narrative rhythms in Giryama Ngano: oral patterns, musical patterns and musical structure. In Isidore Okpewho (ed.), The Oral Performance in Africa (pp. 208-227). Ibadan: Spectrum.

Behrendt, S. C. (2008). Using contextual analysis to evaluate texts. Available at: http://wwww.gotavard.ga/go/?u=http:english.un.edu/sbehrendt/Study/Questions/ContextAnalysis.html

Carlson, M. (1996). Performance: A Critical Introduction. London and New York: Routledge.

Childs, P. and Fowler, R. (2006). The Routledge Dictionary of Literary Terms. New York: Routledge and Kegan Paul. https://doi.org/10.4324/9780203462911

Chukwuma, H. (1994). Igbo Oral Literature: Theory and Tradition. Enugu: Belpot.

Egudu, R. N. and Nwoga D. I. (1971). Poetic Heritage: Igbo Traditional Verse. Enugu: Nwankwo Ifejika.

Ekpere na Abu (n.d.) (Revised and Enlarged Edition) Ibadan: CSS Bookshop.

Emezue, G. M. T. (2001). African Dirge Poetry. Enugu: Handel Books.

Erim, O. E. (1990). Songs as sources of history. In Bassey W. Andeh (ed.), Cultural Resources Management: An African Dimension (pp. 54-62). Ibadan: Wisdom.

Finnegan, R. (1970). Oral Literature in Africa. Oxford: OUP.

Finnegan, R. (2010) Studying the oral literature of Africa in the 1960s and today Journal des Africanistes, 80(1/2), 15-28.

Goffman, E. (1959). The Presentation of Self in Everyday Life. New York: Doubleday Anchor.

Mbah, B. M. and Mbah E. E. (2007). Azuonye: Lectures on Igbo Literature and Stylistics. Nsukka: UNN Press.

McAuley, G. (2010). Interdisciplinary Field or Emerging Discipline? Performance Studies at the University of Sydney. In Jon McKenzie, Heike Roms, and C. J.W. -L Wee, (eds.), Contesting Performance: Global Sites of Research (pp. 37-50). Basingstoke: Palgrave Macmillan. https://doi.org/10.1057/9780230279421_3

Nwosu, O. B. (2009). Form and Functions of the Oral Poetry of Awuchinumo Community, Imo State Nigeria, M. A. Thesis, University of Abuja.

Ogbalu, C. F. (1989). Igbo Poems and Songs. Onitsha: University Publishing.

Okoh, N. (2002). Preface to Oral Literature. Port Harcourt: Lamson.

Okpewho, I. (1992). African Oral Literature: Background, Character and Continuity. Bloomington and Indianapolis: Indiana University.

Onanuga, S., et al. (2012). The Business Culture of the Igbo: A Model for the Nigeria Economy. Lagos: Silverpen.

Onyeji, C. (2004). Igbo rural women in Africa as creative personalities: musical processing of socio-economic solidarity. Journal of the Musical Arts in Africa, 1, 84-101. https:// doi.org/10.2989/18121000409486689

Opata, D. (1988). Death and reincarnation as window into the nature of existence among the Igbo. Essays on Igbo Worldview (pp.107-125). Enugu and Nsukka: AP Express \& Auto Century.

Sanka, C. G. (2010). The Sisaala Dirge: A Critical Analysis. Ph.D Dissertation, Kwame Nkrumah University of Science and Technology.

Schechner, R. (2013). Performance Studies: An Introduction. Oxon \& Ney York: Routledge. https://doi.org/10.4324/9780203715345 
Udeh, I. E. (2000). Art and culture in the elegiac lore of the Abiriba Igbo, Ph.D. Dissertation. University of Nigeria, Nsukka.

Uzochukwu, S. (1983) Traditional poetry as mirror of cultural values: the case of Igbo funeral chants. Nka: A Journal of Arts, 1.64-74.

Uzochukwu, S. (2001). Traditional Funeral Poetry of the Igbo. Lagos: University of Lagos Press. 